of Psychiatry, but it is, I believe, as fictional as the rest of the book. Its authors are said to be a Robert Wenn MB BCh, MRCPsych and Antonio Camia, MA, MB, DRCOG, MRCPsych, but their names do not appear in the current Medical Register or list of Members of the College of Psychiatrists. I could find no evidence either that there is a journal called the British Review of Psychiatry.

A clue to the solution to the problem may lie in the acknowledgement Ian McEwan gives to Ray Dolan, his 'friend and hiking companion'. Could this be Dr Raymond Dolan, FRCPsych, Consultant Psychiatrist at the National Hospital for Neurology and Neurosurgery, and a colleague of McIvor? If so, a brief exchange between the two of them, perhaps in a corridor at Queen Square, might clarify the matter.

KENNETH GRANVILLE-GROSSMAN, Honorary Consulting Psychiatrist, St Mary's Hospital, London W2

Sir: Unless Mclvor (Psychiatric Bulletin, January 1999, 23, 61) has access to more information than is given in the book, then he has fallen nicely into Ian McEwan's trap!

The paper that Ian McEwan refers to at the end of his book in Acta Psychiatrica Scandinavica does not exist, and the authors' surnames Wenn and Camia is an anagram of Ian McEwan.

RoBin G. MCCREADIE, Director, Department of Clinical Research, Crichton Royal Hospital. Dumfries DG1 4TG

\section{Value of the BJP}

Sir: Dr Weaver (Psychiatric Bulletin, December 1998, 22, 771) is mistaken in his assumption that dispensing with the British Joumal of Psychiatry (BJP) as an automatic membership entitlement would release funds to use for other purposes. In fact, far from contributing to the College's costs, the BJP's subscription, advertising and other secondary forms of income generate a substantial surplus for the College. This surplus is used to further the College's many other activities, and hence the journal has the net effect of lowering rather than raising membership fees.

The appeal of the BJP to its authors and advertisers is linked to its extensive readership in the profession. This appeal would be lessened if the circulation were to be significantly reduced, and any short-term saving on the cost of supplying individual members would soon be encompassed by a longer term decline in the journal's income.

We are naturally concerned that Dr Weaver is unconvinced of the relevance of the BJP to his own sub-speciality. The recent survey of members' views (Kendell \& Duffett, 1999) showed that the BJP is valued highly by the majority. However, we are always keen to make improvements where possible, and will take his comments on board when planning our future development.

We are very grateful to Professor Richard Harrington and Professor Sir Michael Rutter for their helpful ongoing advice to the Editorial Board on increasing the relevance of the BJP for our readers in child and adolescent psychiatry. Dr Weaver may be interested to hear that we have just invited a third representative of the speciality, Professor Simon Gowers, to join the Board.

\section{Reference}

KENDELl, R. E. \& DUFFETT, R. (1999) The College: an analysis of members views. Psychiatric Bulletin. 23. 11-15.

GREG WILKINSON, Editor, British Journal of Psychiatry, and DAVE JAGO, Head of Publications, Royal College of Psychiatrists, 17 Belgrave Square, London SWIX 8PG 